\title{
Toll-Like Receptor (TLR) 2 and TLR9 Expressed in Trigeminal Ganglia are Critical to Viral Control During Herpes Simplex Virus 1 Infection
}

Graciela Kunrath Lima, ${ }^{*}$ Guilherme Pimenta Zolini, ${ }^{\dagger}$ Daniel Santos Mansur, ${ }^{*}$ Bráulio Henrique Freire Lima, ${ }^{\dagger}$ Uschi Wischhoff, ${ }^{\dagger}$ Ruiz Gerhardt Astigarraga, ${ }^{\dagger}$ Marcela França Dias, ${ }^{\dagger}$ Mariana das Graças Almeida Silva, ${ }^{\dagger}$ Samantha Ribeiro Béla, ${ }^{\dagger}$ Lis Ribeiro do Valle Antonelli, ${ }^{\dagger}$ Rosa Maria Arantes, ${ }^{\ddagger}$ Ricardo Tostes Gazzinelli, ${ }^{\dagger \uparrow}$ André Báfica," Erna Geessien Kroon, ${ }^{*}$ and Marco Antônio Campos ${ }^{\dagger}$

From the Departamentos de Microbiologia, ${ }^{*}$ Patologia Geral, ${ }^{\ddagger}$ and Bioquimica e Imunologia, Instituto de Ciências Biológicas, Universidade Federal de Minas Gerais, Belo Horizonte, Brazil; the Laboratório de Imunopatologia, ${ }^{\dagger}$ Centro de Pesquisas René Rachou, Fiocruz, Belo Horizonte, Brazil; the University of Massachusetts Medical School, "T Worcester, Massachusettes; and the Laboratório de Imunologia e Doenças Infecciosas," Departamento de Microbiologia e Parasitologia, Universidade Federal de Santa Catarina, Florianópolis, Brazil

Herpes simplex virus 1 (HSV-1) is a neurotropic DNA virus that is responsible for several clinical manifestations in humans, including encephalitis. HSV-1 triggers toll-like receptors (TLRs), which elicit cytokine production. Viral multiplication and cytokine expression in C57BL/6 wild-type (WT) mice infected with HSV-1 were evaluated. Virus was found in the trigeminal ganglia (TG), but not in the brains of animals without signs of encephalitis, between 2 and 6 days postinfection (d.p.i.). Cytokine expression in the TG peaked at 5 d.p.i. TLR9 ${ }^{-1-}$ and TLR2 $/ 9^{-1-}$ mice were more susceptible to the virus, with $60 \%$ and $100 \%$ mortality, respectively, as opposed to $10 \%$ in the WT and TLR2 ${ }^{-/-}$mice. Increased levels of both CXCL10/IP-10 and CCL2/MCP-1, as well as reduced levels of interferon- $\gamma$ and interleukin 1- $\beta$ transcripts, measured in both the TG and brains at 5 d.p.i., and the presence of virus in the brain were correlated with total mortality in TLR2/9 ${ }^{-/-}$mice. Cytokine alterations in TLR2 $/ 9^{-/}$mice coincided with histopathological changes in their brains, which did not occur in WT and $\mathrm{TLR2}^{-1-}$ mice and occurred only slightly in TLR9 $^{-/-}$mouse brain. Increased cellularity, macrophages, CD8 T cells producing interferon- $\gamma$, and ex- pression levels of TLR2 and TLR9 were detected in the TG of WT-infected mice. We hypothesize that HSV-1 infection is controlled by TLR-dependent immune responses in the TG, which prevent HSV-1 encephalitis. (Am J Pathol 2010, 177:2433-2445; DOI: 10.2353/ajpath.2010.100121)

Herpes simplex virus 1 (HSV-1) infections are widespread, and seropositivity may exceed $70 \%$ of the world population. ${ }^{1,2}$ The virus is transmitted primarily by contact between skin or mucosa with contaminated oral secretions. ${ }^{3}$ Primary infections are usually acquired during childhood and often present as mild self-limiting pharyngitis or are asymptomatic. ${ }^{3}$ After HSV-1 replicates in the skin and mucosa, it reaches the dorsal root ganglia termini, from which it is intraxonally transported to the trigeminal ganglia (TG), where it becomes latent. ${ }^{4,5} \mathrm{HSV}-1$ reactivation may be stimulated by hormonal alterations, UV exposure, and immunosuppression, but the mechanisms that underlie reactivation are not well understood. ${ }^{3}$ The virus causes a wide range of manifestations, from the most common herpes labialis to herpes keratitis, which is a major cause of blindness in developed countries. ${ }^{2}$ HSV-1 is also the leading cause of sporadic encephalitis in immunocompromised as well as in immunocompetent individuals and without early manage-

Supported by the Fundação de Amparo à Pesquisa do Estado de Minas Gerais (Brazil), the Conselho Nacional de Desenvolvimento Científico e Tecnológico (Brazil), Instituto Nacional de Ciência e Tecnologia de Vacinas/Conselho Nacional de Desenvolvimento Cientifico e Tecnológico (INCTV/CNPq; Brazil), Coordenação de Aperfeiçoamento de Pessoal de Nivel Superior (CAPES, Brazil), and the Programa Estratégico de Pesquisa em Saúde IV (PAPES) IV/FIOCRUZ/CNPq (Brazil). E.G.K., M.A.C., R.T.G., A.B., L.R.A., and R.M.A. have fellowships from CNPq.

G.K.L. and G.P.Z. contributed equally to this work.

Accepted for publication July 15, 2010

None of the authors disclosed any relevant financial relationships.

Supplemental material for this article can be found on http://ajp. amjpathol.org

Address reprint requests to Marco Antônio Campos, Ph.D., Laboratório de Imunopatologia, CPqRR/FIOCRUZ. Av. Augusto de Lima, 1715. CEP: 30.190-002 Belo Horizonte, MG, Brazil. E-mail: marcoasc@cpqrr. fiocruz.br. 
ment is usually fatal. ${ }^{6}$ Although drug treatment has improved the outcome of these patients, morbidity remains high, and many individuals suffer from relapses or do not respond well to treatment. ${ }^{6}$ The mechanisms underlying HSV-1 manifestations, especially encephalitis, have not been well defined but involve the immune system.

Toll-like receptors (TLRs) are membrane-bound pattern recognition receptors that recognize pathogen-associated molecular patterns in endosomes (TLR3, 7 to 9) and the extracellular space (all remaining TLRs)., ${ }^{7,8}$ There are 10 human (TLRs 1 to 10) and 12 murine (TLR1 to 9 and TLR11 to 13) TLR family members. ${ }^{7,8}$ Since the first description of TLRs in mammals, many TLR agonists have been described: peptidoglycans ${ }^{9}$ and the Trypanosoma cruzi glycosil phosphatidylinositol (GPI) anchor for TLR2 ${ }^{10}$ lipopolysaccharide (LPS) for TLR4, ${ }^{11-14}$ double-stranded RNA (dsRNA) for TLR3 ${ }^{15}$ flagellin for TLR5, ${ }^{16}$ and CpG DNA for TLR9. ${ }^{17}$ TLRs activate inflammatory responses and modulate immunity by several different signal transduction pathways. The most well-characterized pathway involves myeloid differentiation factor 88 (MyD88), an adapter molecule composed of a Toll-interleukin-1 receptor domain and a death domain. ${ }^{18}$ MyD88 recruits the serine/threonine kinase interleukin (IL) receptor associated kinase-4, which activates tumor necrosis factor (TNF)- $\alpha$ receptor-associated factor-6 that, in turn, phosphorylates inhibitor NF kappa B kinase $(\mathrm{IkB})$ and causes it to dissociate from and release nuclear factor $\kappa B$ in the cytoplasm. Nuclear factor $\kappa B$ then translocates to the nucleus and acts as a transcription factor of innate immunity-associated genes. ${ }^{18,19}$ In addition, TLR3 appears to activate the inflammatory response through another adapter molecule, named Toll-interleukin-1 receptor domain-containing adaptor-inducing interferon (IFN) $\beta{ }^{19}{ }^{19}$ This pathway is MyD88 independent and culminates with the translocation of interferon regulatory factor 3 to the nucleus, leading to the production of IFN $\beta$ and IFN-inducible genes. ${ }^{19}$

Many studies have examined the participation of innate immunity in HSV-1-related diseases and in the control of infection. In particular, TLRs have been intensively investigated. In 2004 Kurt-Jones et al ${ }^{20}$ demonstrated that HSV-1 activated TLR2 in vitro and that TLR2 null $\left(^{-/-}\right)$mice inoculated intraperitoneally with HSV-1 KOS showed increased resistance to infection. In the same year, Hochrein et $a^{21}$ and Krug et al ${ }^{22}$ showed that TLR9 was important for the dendritic cell response to HSV-1. However, Krug et $\mathrm{al}^{22}$ could not find differences in viral replication or in susceptibility in $\mathrm{TLR9}^{-1-}$ and MyD88 ${ }^{-1-}$ mice infected in the footpad or in the corneas with HSV-1. Nevertheless, our group ${ }^{23}$ demonstrated that TLRs (and/or IL-1 $\beta$ ) are essential to control the virus in an intranasal model of HSV-1 infection because $100 \%$ of MyD88 $8^{-I-}$ mice developed lethal encephalitis after viral inoculation. We also showed that $50 \%$ of the inoculated IFN- $\gamma$ knockout (KO) mice died from encephalitis. ${ }^{23}$ Additionally, cooperation between TLR2 and TLR9 in HSV control has been demonstrated in HSV-1 infected dendritic cells ${ }^{24}$ and, more recently, in an HSV-2 mouse model of vaginal and intraperitoneal infection. ${ }^{25}$ TLRs have also been proposed to be important in Herpes simplex encephalitis in humans..$^{26,27}$
How innate immunity and which TLRs contribute to the control of HSV-1 and related diseases are still unknown. In this study, we investigated how HSV-1 infection is controlled in a murine model of intranasal infection by using the HSV-1 EK strain, which was isolated from a human case of recurrent oral herpes with blisters. Our experiments indicated that in C57BL/6 wild-type (WT) mice, control of virus infection seemed to be highly regulated at the level of the TG. The levels of cytokine transcripts were directly related to the viral load in TG, and once the virus was controlled, the cytokine levels were reduced. Additionally, we found that TLR2 and, more importantly, TLR9 play a role in immune responses and immune control in the TG and mouse brain. Thus, it seems that HSV-1 infection control in the intranasal murine model occurs in the TG and brain, and TLR deficiencies may cause deregulated inflammation in these organs, which consequently allows virus entry into the brain and raises the susceptibility of mice to infection.

\section{Materials and Methods}

\section{Virus}

HSV - 1 strain EK, ${ }^{28}$ isolated from a human case of recurrent oral herpes with blisters, was multiplied in Vero cells as previously described ${ }^{23}$ and purified as previously described. ${ }^{29}$ The virus titers obtained were $3.0 \times 10^{9}$ plaque forming units (PFU)/ml.

\section{Vero Cells}

Vero cells (American Type Culture Collection, Manassas, VA) were maintained in minimal essential medium supplemented with $5 \%$ heat-inactivated fetal bovine serum and antibiotics in $5 \% \mathrm{CO}_{2}$ at $37^{\circ} \mathrm{C}$. These cells were used for multiplication and titration of the virus.

\section{Human Embryo Kidney Cells}

Human embryo kidney (HEK) 293 cells stably transfected with the pcDNA3 plasmid (Invitrogen, Carlsbad, CA) containing the human TLR2, TLR4MD.2, or TLR9 sequences or the empty vector, each fused with yellow fluorescent protein, were a kind gift from Dr. Douglas T. Golenbock (Division of Infectious Diseases and Immunology, Department of Medicine, University of Massachusetts Medical School, Worcester, MA). Cells were stimulated with HSV-1 $\left(10^{5} \mathrm{PFU} / \mathrm{ml}\right.$ or at multiplicities of infection [MOls] of 2 or 10), LPS (100 ng/ml; from Escherichia coli, 055:B5; Sigma, St. Louis, MO), Malp-2 (10 ng/ml; Alexis Biochemicals, San Diego, CA), CpG 2006 and 1826 (5 $\mu \mathrm{mol} / \mathrm{L}$; Alexis Biochemicals), or E. coli (100 units/cell) for 6 or 24 hours. Human IL-8 was measured by enzymelinked immunosorbent assay (ELISA; BD, Franklin Lakes, $\mathrm{NJ}$ ) in the supernatants of HEK293, HEK TLR4, and HEK TLR2 cells 24 hours after stimulation, and the relative increase in luciferase activity was measured in HEK TLR9 cells 6 hours after stimulation. 


\section{Intraperitoneal Macrophages}

Thioglycollate-elicited peritoneal macrophages were obtained from either C57BL/6, TLR2 ${ }^{-1-}$, $\mathrm{TLR}^{-1-}$, or TLR2/ $9^{-1-}$ mice by peritoneal washing, activated with murine IFN- $\gamma$ as previously described, ${ }^{23}$ and then stimulated with HSV-1 (MOI of 10) for 24 hours. Murine TNF $\alpha$ and IL-12 p40 were measured in the supernatants by ELISA (BD).

\section{Mice}

$\mathrm{TLR}^{-1-}$ and $\mathrm{TLR9}^{-1-}$ mice were generated at Osaka University (Osaka, Japan) and were kind gifts from Shizuo Akira, and the TLR2/9 $9^{-1-}$ mice were obtained by crossing $\mathrm{TLR}^{-1-}$ and $\mathrm{TLR9}^{-1-}$ mice at the National Institutes of Health (Bethesda, MD) and were kind gifts from Alan Sher. The mice were backcrossing to the C57BL/6 background for eight generations. The C57BL/6 (wild-type, control) and the knockout mice were maintained in a pathogen-free, barrier environment in the Centro de Pesquisas René Rachou, Oswaldo Cruz Foundation (CPqRR/FIOCRUZ; Belo Horizonte, Minas Gerais, Brazil). Six- to ten-week-old male mice were anesthetized with ketamine (Agribrands do Brasil Ltda, Brazil), and $10^{6}$ PFU of purified HSV-1 in $10 \mu$ was inhaled by the mice as described previously. ${ }^{30}$ The control mice inhaled PBS. The mouse colonies and all experimental procedures were performed according to the institutional animal care and use guidelines from the CPqRR/FIOCRUZ. The project was previously approved by the Ethics Committee on Animal Experimentation (Comitê de Ética em Experimentação Animal (CETEA) from Universidade Federal de Minas Gerais (UFMG) and Comitê de Ética em Utilizaçào de Animais (CEUA) from CPqRR/FIOCRUZ).

\section{Tissue Culture Infectious Dose Titration}

Frozen mouse tissues were ground with sterile sand and $300 \mu$ l (trigeminal ganglia) or $500 \mu l$ (brains) of Dulbecco's modified Eagle's medium containing 1\% fetal bovine serum and antibiotics. Then the samples were centrifuged at $6700 \mathrm{~g}$ for 10 minutes at $4^{\circ} \mathrm{C}$, and the supernatants were used for titration in a standard tissue culture infectious dose $\left(\mathrm{TCID}_{50}\right)$ assay. ${ }^{31}$

\section{RNA Extraction}

Trigeminal ganglia and brains were aseptically removed and stored at $-70^{\circ} \mathrm{C}$ until processing. RNA extraction was performed by using the TRIzol reagent (Invitrogen) according to the manufacturer's procedures. One microliter of the extracted RNA was quantified with a Nanodrop ND-1000 spectrophotometer at wavelengths of 260 and $280 \mathrm{~nm}$.

\section{Reverse Transcription}

Reverse transcription was performed according to the procedures provided by the manufacturer of the M-MLV RT enzyme (Promega, Madison, WI).

\section{Real-Time PCR}

Real-time quantitative PCR (Applied Biosystems, Carlsbad, CA) was performed to measure mRNA expression in the trigeminal ganglia and brains of mice infected with HSV-1. The reactions were performed by using the SYBR Green PCR Master Mix (Applied Biosystems) in an Applied Biosystems 7000 Sequence Detection System and at $50^{\circ} \mathrm{C}$ for 2 minutes, $95^{\circ} \mathrm{C}$ for 10 minutes, and 40 cycles of $95^{\circ} \mathrm{C}$ for 15 minutes and $60^{\circ} \mathrm{C}$ for 1 minute, followed by a final dissociation stage. The following oligonucleotides were used in the reactions: Hypoxanthine-guanine phosphoribosyltransferase (forward: 5'-GTTGGATACAGGCCAGACTTTGTTG-3'; reverse: 5'-GATTCAACTTGCGCTCATCTTAGGC-3'); IFN $\beta$ (forward: 5'-CTGGAGCAGCTGAATGGAAA-3'; reverse: 5'-TGTCTGCTGGTGGAGTTCAT-3'); IP-10 (CXCL10; forward: 5'-GCCGTCATTTTCTGCCTCAT-3'; reverse: 5'-GCTTCCCTATGGCCCTCATT-3'); MCP-1 (CCL2; forward: 5'-CTTCTGGGCCTGCTGTTCA-3'; reverse: 5' CCAGCCTACTCATTGGGATCA-3'); MIP-1 $\alpha$ (CCL3; forward: 5'-ACTGCCTGCTGCTTCTCCTA-3'; reverse: 5'TTGGAGTCAGCGCAGATCTG-3'32); IL-1 $\beta$ (forward: 5'CGCAGCAGCACATCAACAAGAGC-3'; reverse: 5'-TGTCCTCATCCTGGAAGGTCCACG-3'); $\alpha$ trans-inducing factor (forward: 5'-TTTGACCCGCGAGATCCTAT-3'; reverse: 5'-GCTCCGTTGACGAACATGAA-3'33); TLR2 (forward: 5' TTGCTCCTGCGAACTCCTAT-3'; reverse: 5'-AGCCTGGTGACATTCCAAGA-3'); and TLR9 (forward: 5'-ACCTCAGCCACAACATTCTC-3'; reverse: 5'-TGCACCTCCAACAGTAAGTC-3'. ${ }^{34}$ The comparative Ct method with the formula $2^{-\Delta \Delta C t}$ was used to analyze the data. Gene expression was normalized to the expression of the constitutively expressed gene Hypoxanthine-guanine phosphoribosyltransferase. All reactions were replicated.

\section{ELISA Assays}

Supernatants from HEK293 cells (empty vector and TLR2 and TLR4MD.2 transfected cells) were tested for the presence of human IL-8 (BD) according to the manufacturer's protocols. Supernatants from macrophages stimulated with HSV-1 were tested for the presence of murine TNF $\alpha$ and murine IL-12 p40 (BD) according to the manufacturer's protocols. Mice sera were tested for the presence of murine IL-1 $\beta$ and CXCL10 (IP10) by using ELISA kits (R\&D Systems, Minneapolis, MN) and for murine IFN- $\gamma$ and CCL2 (MCP1) by using the cytometric bead array (CBA) mouse inflammation kit (BD) according to the manufacturer's protocols.

\section{Luciferase Activity Measurement}

HEK TLR9 cells were cultured in 96-well plates $\left(2 \times 10^{4}\right.$ cells/well). After incubation for 1 day, cells were transiently transfected (using Genejuice [Novagen, Darmstadt, Germany] according to manufacturer's instructions) with a plasmid containing an artificial promoter preceding the firefly luciferase gene with five binding sites for nuclear factor $\kappa \mathrm{B}$. Cells were also co-transfected with a plasmid containing a constitutively expressed Renilla-luciferase reporter gene 
(Promega). After 24 hours, the cells were stimulated as described in Human Embryo Kidney Cells. After 6 hours, the cells were lysed, and $20 \mu$ l of each protein extract was used for the activity measurement. Extracts were distributed in 96-well plates, and $100 \mu$ l of luciferin was added to each well at room temperature immediately before the reading. Luciferase activity levels were detected in a Lumat LB 9501 over 10 seconds of luminosity.

\section{Histopathology}

Brain samples were fixed with 10\% formaldehyde in phosphate buffer, routinely processed, and embedded in paraffin as previously described. ${ }^{23}$ For each group, topographically matched temporal lobe and periventricular white matter consecutive sections were scored in 14 microscopic fields (20× objective; $n=3$ per group). The histopathological aspects of parenchyma and meninges were evaluated by vascular reactivity (endothelial reactivity and proliferation and level of perivascular cell infiltration) and scored as mild $(+)$, moderate $(++)$, or intense $(+++)$. Vascular changes, edema, and cell infiltration of leptomeninges were scored as mild $(+)$, moderate $(++)$, or intense $(+++)$.

\section{Histopathology and Immunostaining}

For trigeminal ganglia immunostaining, samples were frozen in Tissue-Tek O.C.T. compound (Sakura, Finetek, Torrance, CA), and 5- $\mu \mathrm{m}$ slices were cut with a HM505N microtome cryostat (Mikron, Vista, CA). Tissues were stained as previously described ${ }^{35}$ with modifications (see Supplemental Figure 1, A-E, at http://ajp.amjpathol.org). Briefly, the tissue sections were incubated with primary antibodies for 2 hours, washed, and incubated with labeled secondary antibody. The sections were counterstained with Hoechst and mounted in Hydromount aqueous medium (National Diagnostics, Atlanta, GA). The primary antibodies used were CD3 (1:100) and CD8 (1:100; Serotec, Raleigh, $\mathrm{NC})$. The secondary antibody was Alexa Fluor 488 goat anti-rat IgG (1:500; Molecular Probes, Carlsbad, CA). Nuclei counterstaining was performed by using Hoechst $(0.2$ $\mu \mathrm{g} / \mathrm{ml}$; Molecular Probes). The stained sections were observed and photographed on an Olympus BX51 microscope (Olympus, Tokyo, Japan) by using a Megacybernetics color digital camera and the Image Pro-Express software.

\section{Cell Preparation and Flow Cytometry}

Single-cell suspensions were prepared from the TG of WT mice that were divided into control and infected groups. Tissues were digested with collagenase for 30 minutes at $37^{\circ} \mathrm{C}$. After incubation, the TGs were disrupted by grinding with a syringe plunger. The cells were washed, suspended in RPMI with $10 \%$ fetal bovine serum, and counted by trypan blue exclusion with high viability. A total of $10^{6}$ cells were plated for macrophage and dendritic cell measurements, and $5 \times 10^{5}$ for CD4, CD8, and natural killer (NK) cell measurements. Cells were incubated for 1 hour in $5 \%$ $\mathrm{CO}_{2}$ at $37^{\circ} \mathrm{C}$. Then the BD GolgiPlug Protein Transport
Inhibitor (BD Biosciences, San Jose, CA) was added to the wells where IFN- $\gamma$ production was evaluated, and the plates were incubated for 8 hours. Plates were centrifuged at $532 \times g$ for 5 minutes at $4^{\circ} \mathrm{C}$ and suspended in Fluorescence activated cell sorting (FACS) buffer solution with anti-mouse CD11C (FITC; BD Pharmingen, San Diego, CA), anti-mouse CD11b (PECy7; eBioscience, San Diego, CA), and anti-mouse $\mathrm{F} 4 / 80$ (APC; eBioscience) antibodies to identify macrophages and dendritic cells; with anti-mouse NK1.1 (FITC; BD Pharmingen), anti-mouse CD4 (APC; eBioscience), anti-mouse CD8 (PECy5; BD Pharmingen), and anti-mouse I-A $\mathrm{A}^{\mathrm{b}}$ (PE; BD Pharmingen) antibodies to identify CD4, CD8, and NK cells; and with FC Block (BD Pharmingen) for all of the markers. The cells were then incubated for 20 minutes at room temperature, washed two times, and suspended in $200 \mu$ l of FACS buffer. For T and NK cells marked with IFN- $\gamma$, cells were incubated with BD cytofix/ cytoperm solution ( 15 minutes at $4^{\circ} \mathrm{C}$ in the dark), followed by washing and incubation with BD Perm/Wash solution (150 ml/well). After washing and centrifugation at $532 \times \mathrm{g}$ for 5 minutes at $4^{\circ} \mathrm{C}$, the cells were suspended in $\mathrm{BD}$ Perm/Wash solution with IFN- $\gamma$ (PE; BD Pharmingen) and incubated for 30 minutes at $4^{\circ} \mathrm{C}$ in the dark. The cells were washed with BD Perm/Wash and centrifuged twice $(532 \times$ $g$ for 5 minutes, $4^{\circ} \mathrm{C}$ ). The cells were finally suspended in $200 \mu \mathrm{l}$ of FACS buffer solution. For each sample, between 100,000 and 200,000 events were captured for analysis. The data were analyzed using the FlowJo 7.2.5 software (Tree Star, Inc., Ashland, OR) and are presented as the percentage of positive cells within the gated population.

\section{Statistical Analysis}

The real-time PCR results were statistically analyzed by using Mann-Whitney nonparametric $t$-tests. The HEK cells results were analyzed with analysis of variance tests. The macrophage and flow cytometry results were analyzed with unpaired $t$-tests. The analyses were performed by using the GraphPad Prism 5 software for Windows (GraphPad Software, Inc., La Jolla, CA).

\section{Results}

\section{Infectious HSV-1 Reaches the TG of C57BL/6 Mice on Day 2 Postinfection and Peaks on Day 5 Postinfection}

C57BL/6 WT mice were intranasally infected with $10^{6} \mathrm{PFU}$ of HSV-1. The animals were euthanized over the course of 8 days postinfection (d.p.i.), and the brains and TG were aseptically removed and snap frozen to verify the presence of infectious virus particles. Mouse TG supernatants induced an HSV-1 cytopathic effect in Vero cells from 2 to 6 d.p.i. (Table 1). For a few animals, it was possible to calculate infectious particles in the TG (3 to 5 d.p.i.), with an average of $10^{2,99} \mathrm{TCID}_{50} / \mathrm{ml}$. The mouse brain supernatants did not present any detectable infectious particles. 
Table 1. Kinetics of HSV-1 Multiplication in C57BL/6 Mouse Organs

\begin{tabular}{cccc}
\hline d.p.i. & $\begin{array}{c}\text { CPE of TGs in } \\
\text { Vero cells* }\end{array}$ & TCID $_{50} / \mathrm{ml} \mathrm{in} \mathrm{TGs}^{\dagger}$ & $\begin{array}{c}\text { CPE of brains } \\
\text { in Vero cells* }\end{array}$ \\
\hline 1 & $\mathrm{ND}^{\ddagger}$ & $\mathrm{ND}$ & $\mathrm{ND}$ \\
2 & $+(3 / 4)$ & $\mathrm{ND}$ & $\mathrm{ND}$ \\
3 & $+(3 / 4)$ & $10^{3,3}(1 / 4)$ & $\mathrm{ND}$ \\
4 & $+(3 / 4)$ & $10^{2,8}(1 / 4)$ & $\mathrm{ND}$ \\
5 & $+(3 / 4)$ & $10^{2,7}$ and $10^{2,9}(2 / 4)$ & $\mathrm{ND}$ \\
6 & $+(2 / 4)$ & $\mathrm{ND}$ & $\mathrm{ND}$ \\
7 & $\mathrm{ND}$ & $\mathrm{ND}$ & $\mathrm{ND}$ \\
8 & $\mathrm{ND}$ & $\mathrm{ND}$ & $\mathrm{ND}$
\end{tabular}

${ }^{*}$ Cytopathic effect (CPE) detected in Vero cells infected with TG or brain supernatants; $n / 4$ indicates the number of positive mice in a total of four mice per day.

${ }^{\top} \mathrm{TCID}_{50} / \mathrm{ml}$, median tissue infective dose.

FND, virus was not detected.

\section{Viral, Cytokine, and TLR Transcripts Are Increased in C57BL/6 Mice TG on Day 5 Postinfection}

Another group of C57BL/6 WT mice was intranasally infected with $10^{6}$ PFU of HSV-1. This experiment was performed as described above, except that only TGs were analyzed to verify the expression of viral and cytokine transcripts by real-time quantitative PCR. HSV-1 Virion Protein 16 (VP-16; also known as $\alpha$ trans-inducing factor), a late viral gene expressed only during the replication cycle of the virus, ${ }^{33}$ was detected in mouse TG from 2 to 8 d.p.i. (Figure 1A). The level of the VP-16 transcript increased until 5 d.p.i. (when it had a more pronounced expression) and decreased until 8 d.p.i. (Figure 1A). The cytokines/chemokines IFN- $\gamma$, CXCL10/IP-10, CCL2/ MCP-1, and CCL3/MIP $1 \alpha$ measured in mouse TG showed a similar profile, with increased expression until
5 d.p.i., followed by a decrease until 8 d.p.i., when the levels returned to baseline (Figure 1, B-E). The increase in the transcripts was only statistically significant for the chemokines CXCL10/IP10 (4, 5, and 6 d.p.i.; Figure 1C), CCL2/MCP-1 (5 and 6 d.p.i.; Figure 1D), and CCL3/MIP 1 $\alpha$ (5 d.p.i.; Figure 1E). As for IFN- $\gamma$, the level of the IFN $\beta$ transcript was higher on day 5 postinfection but was not statistically significant (data not shown). TLRs 2 and 9 expression levels were also significantly increased in WT infected mice on day 5 postinfection (Figure 1F). Thus, the presence of infectious virus particles and its replication seemed to correlate with increases in cytokine and TLR expression in the TG of C57BL/6 mice, with a peak of viral and cytokine expression on day 5 postinfection.

\section{HSV-1 Activates TLR2 and TLR9 in Transfected HEK293 Cells}

HEK293 cells stably transfected with plasmids expressing TLR2, TLR4, or TLR9, or an empty vector were stimulated with HSV-1. Control cells had only basal levels of IL-8 expression for all stimuli tested (Figure 2A). In TLR4-expressing cells (Figure 2B), HSV-1 did not stimulate IL-8 production, indicating that our purified virus was not contaminated with LPS and that the virus does not activate this receptor. Only cells expressing TLR2 (Figure 2C) or TLR9 (Figure 2D) were activated after viral stimulation, as measured by the production of IL-8 in the supernatants or by luciferase activity, respectively. These results indicate that TLR2 and TLR9 recognize HSV-1 and stimulate an immune response against the virus.
A

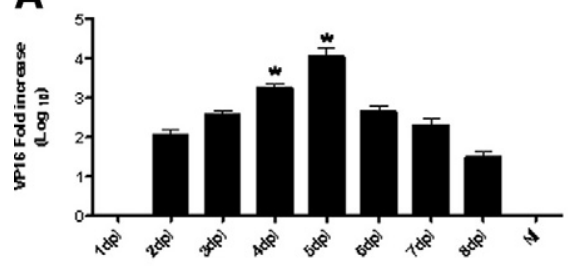

C

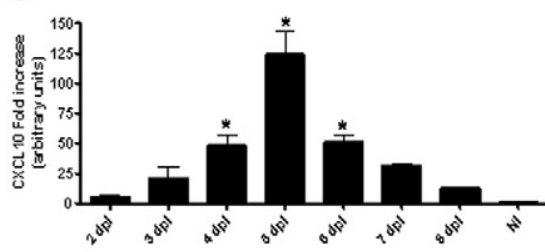

E

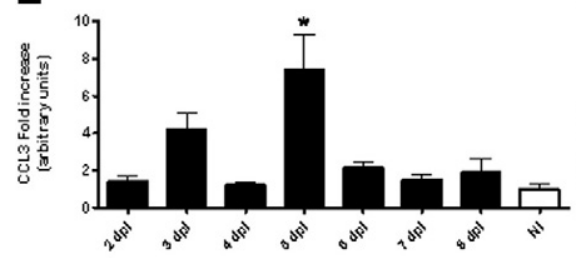

B

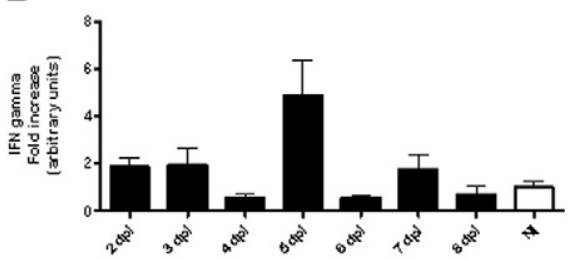

D

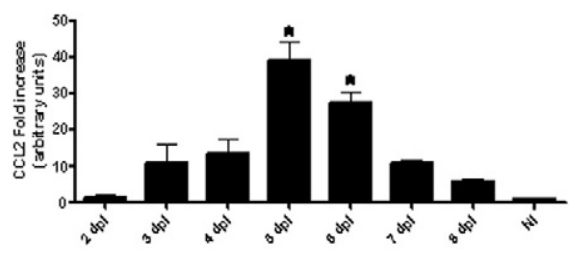

$\mathbf{F}$

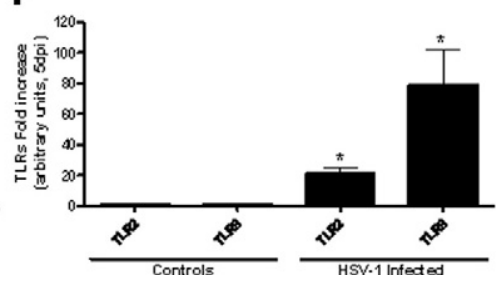

Figure 1. Patterns of viral, cytokine, and chemokine transcript expression and TLR expression in $\mathrm{C} 57 \mathrm{BL} / 6$ mouse trigeminal ganglia. C57BL/6 mice were intranasally infected with $10^{6}$ PFU HSV-1, and four pools of trigeminal ganglia of three animals were collected each day from 1 to 8 d.p.i. Uninfected mice (NI) aspirated only PBS. After RNA extraction and reverse transcription, real-time PCR was performed. (A) VP-16 HSV-1 transcript; (B) IFN- $\gamma$; (C) CXCL10 (IP-10); (D) CCL2 (MCP-1); and (E) CCL3 (MIP 1 $\alpha)$. In F, TLR2 and 9 expression levels were measured in WT mice on day 5 postinfection ${ }^{*} P<0.05$. Statistical analyses were performed with Kruskal-Wallis nonparametric tests and Dunn's multiple comparison tests. Bars represent the SEM. The results shown are representative of two experiments that yielded similar results. 
A

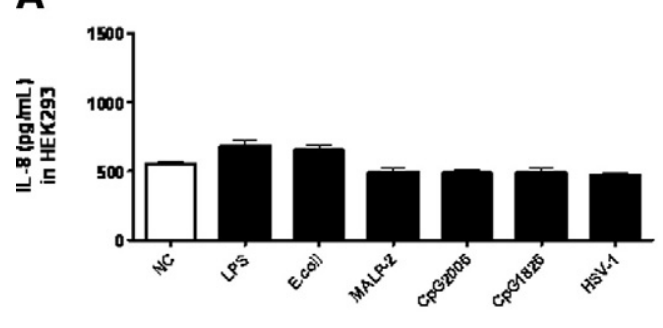

B
C

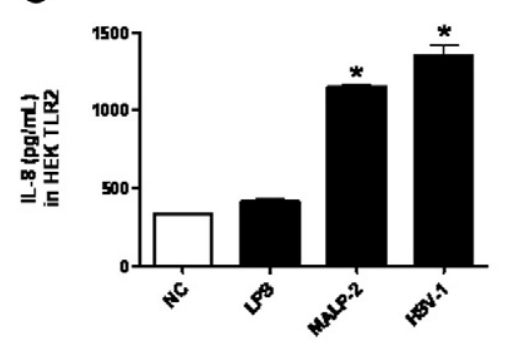

D

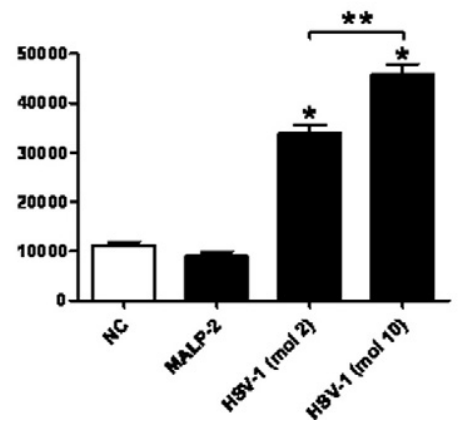

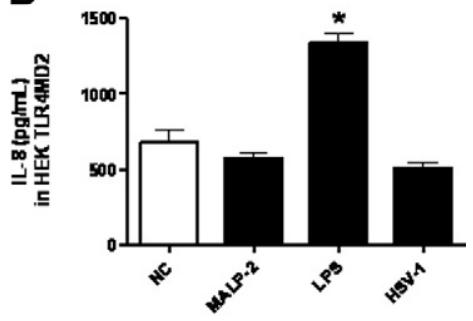

Figure 2. TLR 2 and TLR9 activation in HEK cells after HSV-1 stimulation. HEK cells were stably transfected with plasmids expressing TLR2, TLR4, or TLR9 and were then stimulated with HSV-1 (10 $10^{5} \mathrm{PFU} / \mathrm{ml}$ in $\mathbf{A}, \mathbf{B}$, and $\mathbf{C}$; or at MOIs of 2 and 10 in D), LPS $(10 \mathrm{ng} / \mathrm{ml})$, Malp-2 (10 $\mathrm{ng} / \mathrm{ml}), \mathrm{CpG} 2006$, and $1826(5 \mu \mathrm{mol} / \mathrm{L})$, or $E$. coli (100 units/cell), as indicated in the figure. After 24 hours of stimulation, IL- 8 in the supernatants (for $\mathbf{A}, \mathbf{B}$, and $\mathbf{C}$ ) or the relative increase in luciferase expression (for $\mathbf{D}$ ) was measured. (A) HEK 293; (B) HEK TLR4; (C) HEK TLR2; and (D) HEK TLR9. The results shown are representative of two experiments that yielded similar results. Statistical analyses were performed with analysis of variance tests, and the bars represent the SEM. ${ }^{*} P<0.05$; statistical difference between the bar and the respective negative control (medium stimulated). ${ }^{* * *} P<0.05$; statistical difference between the indicated bars.

\section{TLR2 and TLR9 Contribute to Production of IL-12p40 and TNF $\alpha$ in Macrophages}

C57BL/6 WT, TLR2 ${ }^{-1-}$, TLR9 ${ }^{-1-}$, and TLR2/9 ${ }^{-1-}$ mousederived macrophages were stimulated with HSV-1, and the levels of IL12p40 and TNF $\alpha$ were measured in the cell supernatants. All infected macrophages derived from TLR null mice showed reduced production of cytokines when compared with infected macrophages derived from WT infected mice (Figure 3, A and B). TLR2 and TLR9 seemed to contribute synergistically to the production of IL12p40 in macrophages because the double KO mice had a more pronounced reduction in this cytokine compared with the single KOs (Figure 3A).

\section{TLR9 ${ }^{-1-}$ and TLR2/9 ${ }^{-/-}$Mice Have Higher Susceptibility to HSV-1 Intranasal Infection}

C57BL/6 WT, $\mathrm{TLR}^{-1-}$, TLR9 ${ }^{-1-}$, and TLR2/9-1- mice were intranasally infected with $10^{6} \mathrm{PFU}$ of HSV-1. Mice were observed daily for clinical signs of encephalitis (prostration, ruffled fur, hunched posture, and posterior paw paralysis). After the symptoms were observed, mice were euthanatized, and their brains were collected and snap frozen to verify the presence of the virus. Most of the mice died on day 6 postinfection, but the TLR2/9 ${ }^{-1-}$ mice began to die earlier than the other groups (Figure 4). C57BL/6 WT and TLR2 ${ }^{-1-}$ infected mice had low mortality rates of around $10 \%$ (Figure 4). TLR9 $^{-1-}$ infected animals had a more pronounced mortality of approximately $60 \%$ (Figure 4). The mortality was even higher for TLR2/9-1- infected mice, with $100 \%$ of the mice dying from infection (Figure 4). Brain $\mathrm{TCID}_{50}$ titrations demonstrated that all euthanized animals with encephalitis had HSV-1 in their brains (Table 2), and the virus titers were two logs higher in TLR9 ${ }^{-1-}$ and TLR2/9 ${ }^{-1-}$ mice and one log lower in TLR2 ${ }^{-1-}$ mice compared with the titer of WT mice (Table 2). Infectious virus particles were not found in the brains of mice without signs of encephalitis (Table 2).

\section{TLR2/9 ${ }^{-/-}$Mice Have Major Histopathological Changes in the Brain on Day 5 Postinfection}

For all experiments described from this point on, C57BL/6 WT, TLR2 ${ }^{-1-}$, $\mathrm{TLR}^{-1-}$, and TLR2/9 ${ }^{-1-}$ mice were intranasally infected with $10^{6} \mathrm{PFU}$ of HSV-1. Because the
A

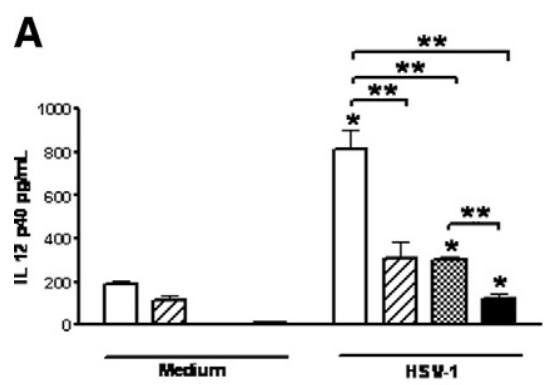

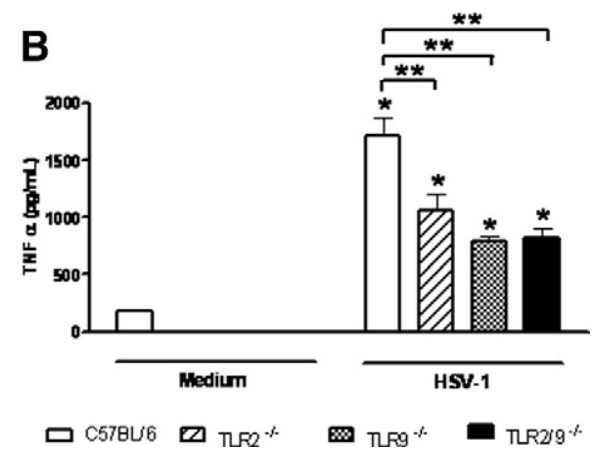

Figure 3. TNF $\alpha$ and IL-12 p40 production in peritoneal macrophages stimulated with HSV-1. $\mathbf{A}$ and $\mathbf{B}$ : Macrophages derived from $\mathrm{C} 57 \mathrm{BL} / 6$ WT mice (white columns), TLR2 ${ }^{--}$mice (striped columns), TLR9 ${ }^{-/-}$mice (pointed columns), or TLR2 $/ 9^{-/-}$mice (black columns) were exposed to HSV-1 (MOI of 10), and the levels of IL12 p40 (A) and TNF $\alpha$ (B) were measured in the culture supernatants 24 hours after stimulation. This experiment is representative of two experiments. Statistical analyses were performed with unpaired $t$-tests, and the bars represent the SEM. ${ }^{*} P<0.05$; statistical difference between the bar and the respective negative control (medium stimulated). ${ }^{* *} P<0.05$; statistical difference between the indicated bars. 


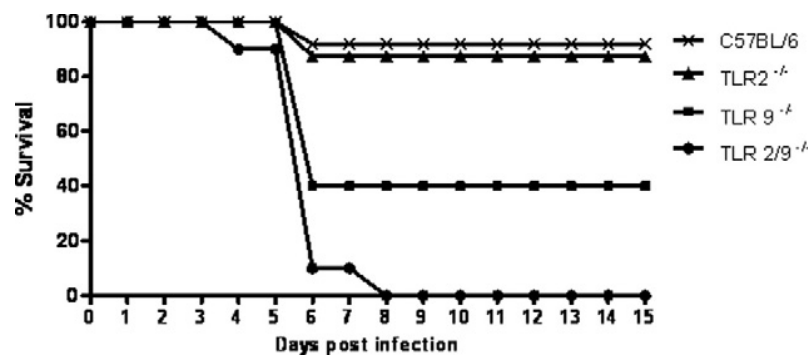

Figure 4. Survival rates of mice intranasally inoculated with HSV-1. C57BL/6 (crosses), TLR2 ${ }^{-1-}$ (triangles), TLR9 ${ }^{-1-}$ (squares), and TLR2/9 ${ }^{-1-}$ (circles) mice were intranasally inoculated with $10^{6}$ PFU HSV-1, and mouse mortality was quantified daily ( $n=10$ for each group). This experiment is representative of three analyses.

previous experiments indicated that 5 d.p.i. was probably an important point for virus control in WT mouse TG and because many mice died after day 5 , we euthanized the animals on day 5 postinfection. Half of each brain was formalin fixed for histopathological analysis. Microscopic examination of the brains stained with H\&E on day 5 postinfection revealed slight endothelial cell reactivity and perivascular edema of parenchyma and meninges of WT and TLR2 ${ }^{-1-}$ infected mice (Figure 5, A-l; Table 3). $\mathrm{TLR9}^{-1-}$ mice presented an intermediate intensity of changes, as shown in Figure 5, A-I, and Table 3. The most severe neuropathological signs of encephalitis were seen in TLR2 $/ 9^{-1-}$ infected mice and were characterized by intense leptomeningitis associated with edema, white matter vacuolization, endothelial reactivity, and perivascular edema (Figure 5, J-L; Table 3). Focal encephalitis characterized by mononuclear cell infiltrates and activated glial cells associated with perivascular cuffing were found exclusively in these animals (Figure 5; Table 3).

\section{Cytokine and Chemokine Transcript Profiles Are Altered in the TG of TLR2/9 ${ }^{-1-}$ Mice on Day 5 Postinfection}

To compare viral and cytokine expression in the TG and brains of WT and knockout mice, sera, TG and half of each brain were aseptically removed from the animals, snap frozen, and processed for analysis. Real-time quantitative PCR indicated that the HSV-1 VP-16 mRNA was detected in similar amounts in TG of mice from all groups (Figure 6A). All cytokine transcripts measured were significantly up-regulated in the TG of all groups of infected mice but in different amounts (Figure 6, B-E). IFN- $\gamma$ (Figure 6B) was downregulated in all infected knockout mice compared with infected WT mice. A lower level of expression of IL-1 $\beta$ (Figure $6 \mathrm{C})$ was found in TLR2/9 $/ 9^{-1-}$ infected mice compared with the other groups of infected animals. CXCL10/IP-10 (Figure 6D) was overexpressed in infected TLR2/9 $9^{-1-}$ animals compared with the other groups. CCL2/MCP-1 (Figure 6E) had a similar profile, but there was not a difference between infected TLR2 $/ 9^{-1-}$ and TLR9 ${ }^{-1-}$ mice. IFN $\beta$ and CCL3/ MIP $1 \alpha$ had similar levels of transcript up-regulation in all infected groups (data not shown).

\section{Cytokine Expression Profile Alterations Are Not

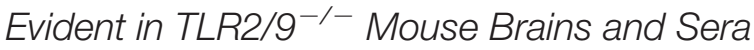 on Day 5 Postinfection}

Brains of the same animals from the experiment described above were analyzed for cytokine transcripts by real-time quantitative PCR. The cytokine transcripts were significantly up-regulated in brains of almost all groups of infected mice (in different amounts; Figure 7, A-D) compared with uninfected mice, except for IFN- $\gamma$ and IL1 $\beta$ transcripts in TLR2/ $9^{-1-}$ mice (Figure 7, A and B) and for IFN- $\gamma$ in WT mice (Figure 7A). CXCL10/IP-10 (Figure 7C) and CCL2/MCP-1 (Figure 7D) were over expressed in infected TLR2/9 $9^{-1-}$ animals compared with the other groups. Unlike the results for TG, IFN- $\gamma$ transcripts (Figure 7A) were not up-regulated in infected C57BL/6 WT mouse brains compared with infected knockouts; however, the transcript levels in brains of infected TLR2 $/ 9^{-1-}$ mice were not increased compared with the respective control mice. A lower level of $\mathrm{IL}-1 \beta$

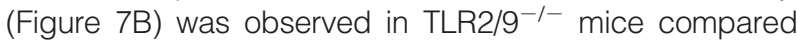
with the other groups of infected animals, but this difference was significant only when compared with infected WT mice. IFN $\beta$ and CCL3/MIP $1 \alpha$ showed similar patterns of upregulation in all infected groups (data not shown). To quantify cytokine production in mice sera, ELISA and CBA were performed. IP-10/CXCL10 and IL $1 \beta$ were not detected in the sera (data not shown), although there were detectable amounts of IFN- $\gamma$ and MCP-1/CCL2 in infected mice compared with controls (Figure 7, E and F). However, only MCP-1/CCL2 exhibited a significant difference between the groups, which was shown by an increase in production in TLR2/9 $/ 9^{-1-}$ when compared with WT mice (Figure 7F).

\section{TG of HSV-1 Infected C57BL/6 Mice Have Increased Macrophage Population in Comparison to TG of Noninfected Mice}

To study the cell populations in TG of infected and noninfected WT mice, we performed Giemsa staining of different areas of WT control (see Supplemental Figure 1A at http://ajp.amjpathol.org) and WT infected (see Supple-

Table 2. HSV-1 Presence in Mouse Brains

\begin{tabular}{|c|c|c|c|c|}
\hline \multirow[b]{2}{*}{ Mouse group } & \multicolumn{2}{|c|}{ Mice without signs of encephalitis } & \multicolumn{2}{|c|}{ Mice with signs of encephalitis } \\
\hline & $\%$ & Mean brain $\mathrm{TCID}_{50} / \mathrm{ml}$ & $\%$ & Mean brain $\mathrm{TCID}_{50} / \mathrm{ml}$ \\
\hline C57BL/6 & 92 & 0 & 8 & $10^{2}$ \\
\hline $\mathrm{TLR}^{-1-}$ & 90 & 0 & 10 & 10 \\
\hline TLR9 $^{-1-}$ & 40 & 0 & 60 & $10^{4}$ \\
\hline TLR2/9-1- & 0 & 0 & 100 & $10^{4}$ \\
\hline
\end{tabular}



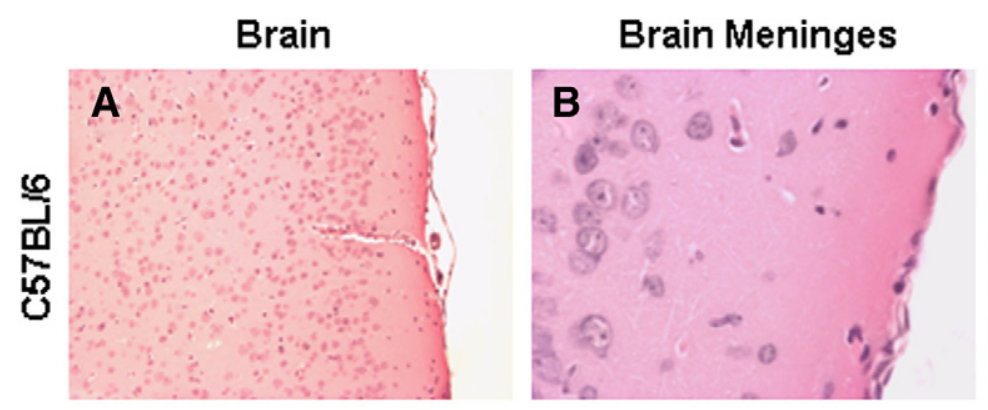

\section{Brain Blood Vessels}
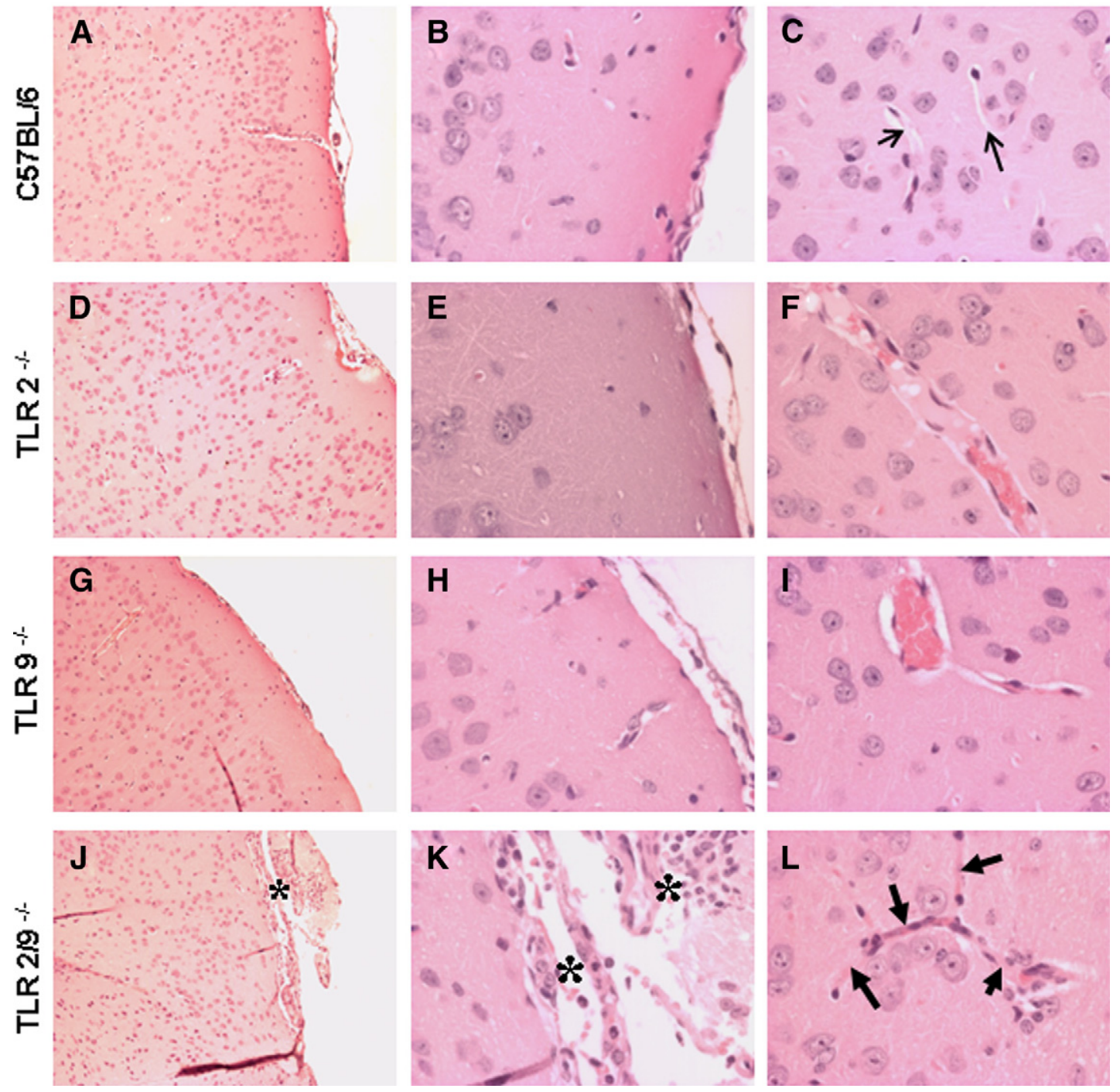

Figure 5. Histopathological analysis of knockout mouse brains on day 5 postinfection. C57BL/6, TLR2 ${ }^{-/-}$, TLR9 ${ }^{-/-}$, and TLR2/9 ${ }^{-/-}$mice were intranasally infected with $10^{6}$ PFU HSV-1, and the brains of three animals per group were collected on day 5 postinfection and processed for histopathological analysis. A-I: Changes in the brain parenchyma and meninges of C57BL/6, TLR2 ${ }^{-/}$, and TLR9 ${ }^{-/-}$mice were mild. J and K: Intense leptomeninges cell infiltration and edema

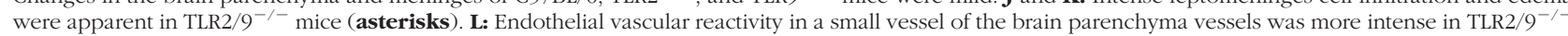
mice (arrows). In $\mathbf{C}$, note the regular aspect of the parenchymal vessels (arrows). Original magnification of the mouse brain, $\times 100$ (left). Original magnification of the mouse brain meninges, $\times 400$ (middle). Original magnification of the mouse brain blood vessels, $\times 400$ (right).

mental Figure 1B at http://ajp.amjpathol.org) ganglia. The data showed increased cellularity of the ganglia root (double asterisks) and close to neurons (single asterisk), where many small mononuclear cells were detected in infected mice (arrows). Furthermore, flow cytometry showed an increase in macrophages in the TG of WT infected mice compared with noninfected mice (Figure 8A).

Table 3. Histopathological Changes in HSV-1-Infected Mice at 5 d.p.i.

\begin{tabular}{lrrr}
\hline Parameters* & $\begin{array}{c}\text { Endothelial reactivity and } \\
\text { proliferation }\end{array}$ & $\begin{array}{c}\text { Perivascular cuffing and } \\
\text { perivascular cell } \\
\text { infiltration }\end{array}$ & $\begin{array}{c}\text { Edema and cell infiltration } \\
\text { of leptomeninges }\end{array}$ \\
\hline Groups & & & $+(3 / 3)$ \\
C57BL/6 & $+(3 / 3)$ & $+(3 / 3)$ & $+(3 / 3)$ \\
TLR2 & $+(3 / 3)$ & $+(3 / 3)$ & $+(3 / 3)$ \\
TLR9 & +- & $++(3 / 3)$ & $+++(3 / 3)$ \\
TLR2/9 & $++(3 / 3)$ & $+++(3 / 3)$ & $+(3 / 3)$ \\
\hline
\end{tabular}

*Histopathological changes were scored as mild + , moderate ++ , or intense $+++;(3 / 3)$, three of three examined animals presented the degree of indicated changes. 
A

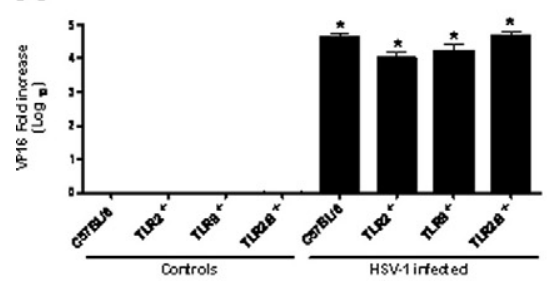

C

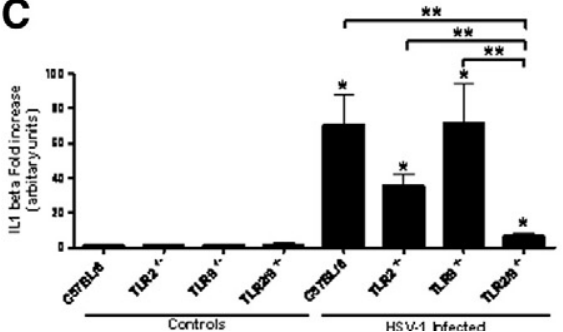

B

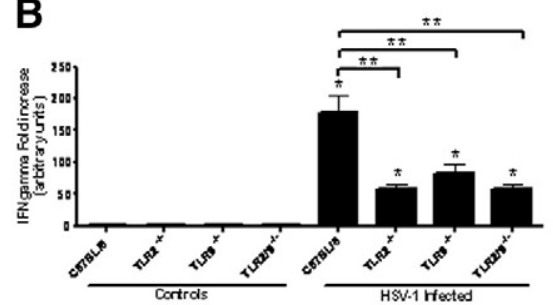

D

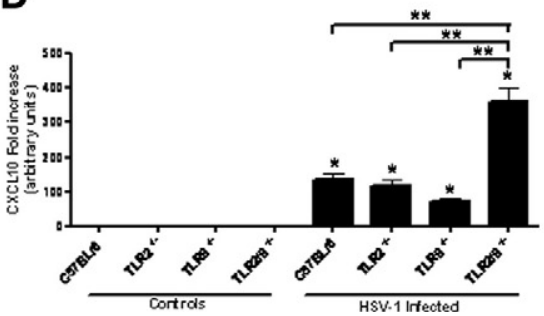

E

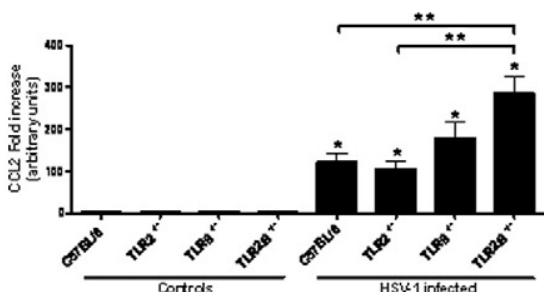

Figure 6. Viral, cytokine, and chemokine transcripts in knockout mouse trigeminal ganglia on day 5 postinfection. C57BL/6, TLR2 ${ }^{-/-}$, TLR9 $9^{-/-}$, and TLR2/9 ${ }^{-/}$ mice were intranasally infected with $10^{6} \mathrm{PFU}$ HSV-1, and trigeminal ganglia of six to nine animals per group were collected on day 5 postinfection. Control mice aspirated only PBS ( $n=4$ for each group). After RNA extraction and reverse transcription, real-time PCR was performed. (A) VP-16 HSV- 1 transcript; (B) IFN- $\gamma$; (C) IL-1 $\beta$; (D) CXCL10 (IP-10); and (E) CCL2 (MCP-1). This experiment is representative of two replicates. ${ }^{*} P<0.05$; statistical difference between the bar and the respective negative control. ${ }^{* *} P<0.05$; statistical difference between the indicated bars. Statistical analyses were performed with Mann-Whitney $t$-tests, and the bars represent the SEM

\section{CD8 Cells Produce a Higher Amount of IFN- $\gamma$ in TG after Infection with HSV-1}

We detected CD3 (see Supplemental Figure 1D at $h t t p: / /$ ajp.amjpathol.org) and CD8 (see Supplemental Figure 1E at http://ajp.amjpathol.org) positive cells in the TG of infected mice but not in noninfected mice (see Supplemental Figure 1C at http://ajp.amjpathol.org). Additionally, we performed flow cytometry analysis of TG after treatment with collagenase. Although the differences in CD8 T cells
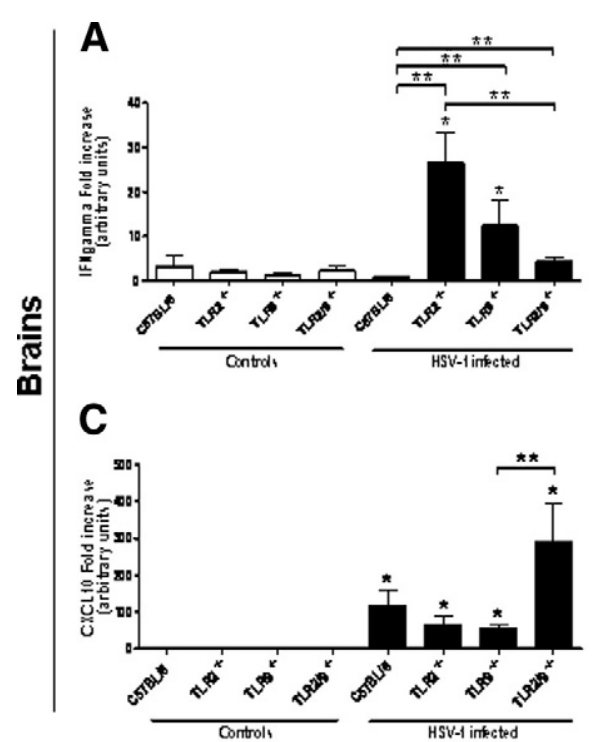

E

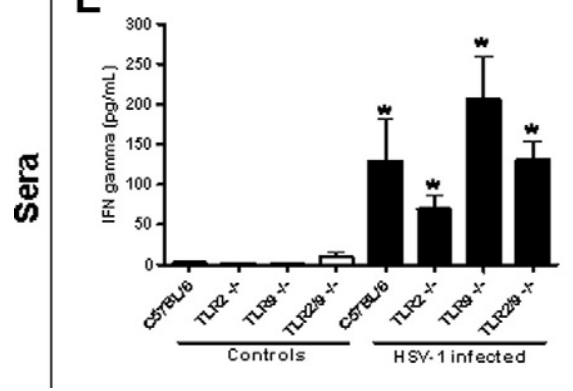

B

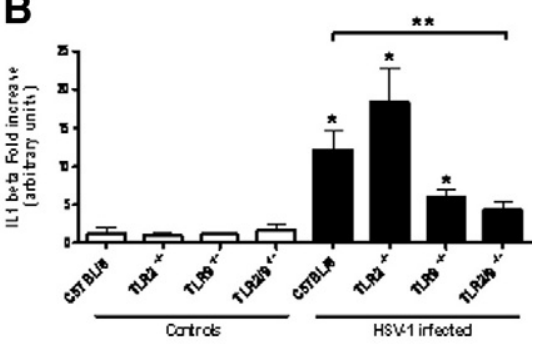

D

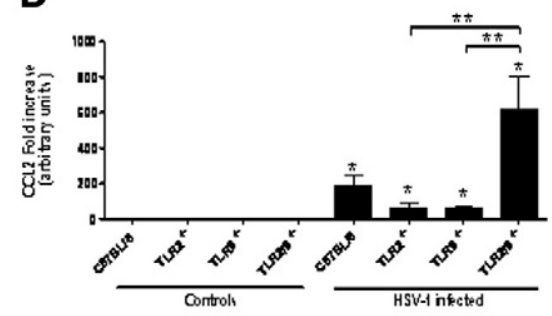

$\mathbf{F}$

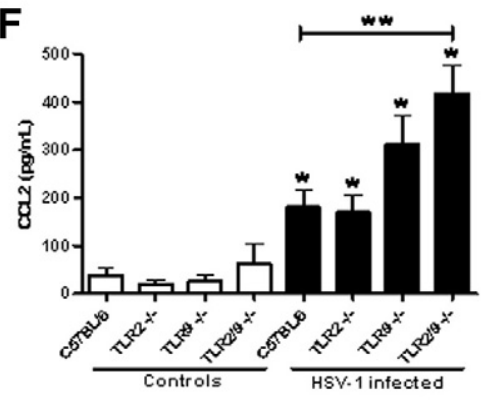

Figure 7. Cytokine and chemokine transcript expression levels in knockout mouse brains and cytokine production in mice sera on 5 d.p.i. C57BL 6 , TLR2 $^{-/-}$, TLR9 $^{-1-}$, and TLR2 $/ 9^{-1}$ mice were intranasally infected with $10^{6} \mathrm{PFU}$ HSV-1, and brains and sera of six to nine animals per group were collected on day 5 postinfection. Control mice aspirated only PBS ( $n=4$ for each group). After RNA extraction and reverse transcription of the brains, real-time PCR was performed. (A) IFN- $\gamma$; (B) IL-1 $\beta$; (C) CXCL10 (IP10); and (D) CCL2 (MCP-1). In the sera, levels of IFN- $\gamma(\mathbf{E})$ and CCL2 (MCP-1; F) were measured by CBA. The results are representative of two experiments that yielded similar results. ${ }^{*} P<$ 0.05 ; statistical difference between the bar and the respective negative control. ${ }^{* *} P<0.05$; statistical difference between the indicated bars Statistical analyses were performed with MannWhitney $t$-tests, and the bars represent the SEM. 
A

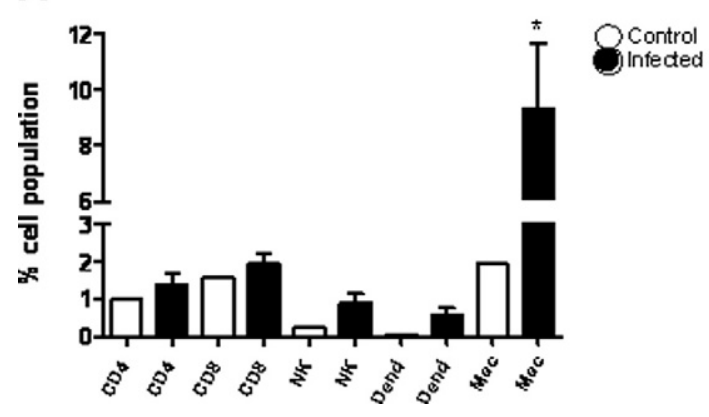

B IFN gamma

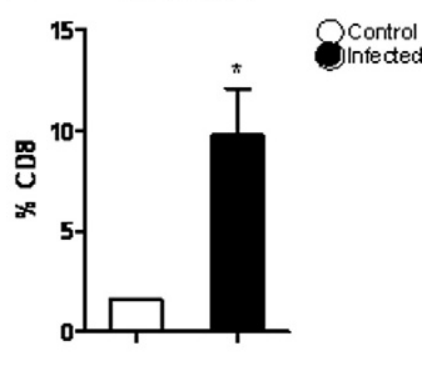

Figure 8. TG of HSV-1-infected C57BL/6 mice have increased macrophage population and CD8 cells that produce IFN- $\gamma$. Mice were intranasally infected with $10^{6}$ PFU of HSV-1, and the TG of five animals per group were collected on day 5 postinfection. Control mice aspirated only PBS ( $n=3$ for each group). TGs were treated with collagenase, and the population of cells was analyzed by flow cytometry by using antibodies against the indicated cells (A). An antibody against IFN- $\gamma$ was used in CD8 T cells $(\mathbf{B})$ All data presented are the mean $\pm \mathrm{SEM} ;{ }^{*} P<$ 0.05 for comparison by $t$-test. were not statistically significant between WT infected and noninfected TG mice (Figure 8A), the CD8 T cells of infected mice produced a higher level of IFN- $\gamma$ than the CD8 T cells of noninfected mice (Figure 8B).

\section{Discussion}

Innate immunity to HSV-1 has been studied by many different research groups in recent years. ${ }^{20-24,26,27,35,36}$ Although these studies show the importance of TLRs and other immune receptors and cytokines/chemokines in HSV-1 recognition and control, some discrepancies remain concerning the benefits of these responses. The differences in results are probably due to the high diversity in the animal models used in these works. ${ }^{37}$ Viral strain, mouse strain, and inoculation route variations may produce different immune responses, ${ }^{38}$ making comparisons between the results of each experiment difficult. However, each different model may have indications for one specific clinical manifestation of the broad spectrum of herpetic manifestations. Our research group uses a strain of HSV-1 that was isolated from a naturally occurring human lip recurrence. Additionally, the intranasal inoculation route that we used in our experiments ${ }^{30}$ is similar to the natural route of infection because the lips (natural infection) and nose have common innervations.

In this work, we demonstrated that most C57BL/6 WT mice, which have a low susceptibility to an intranasal inoculation of $10^{6} \mathrm{PFU}$ of HSV-1, are capable of controlling viral replication in TG, which prevents the infectious virus from reaching the brain, because the infectious virus was found in TG but not in the brains of WT animals. HSV-1 infection generally leads to a localized infection; the virus initiates replication in mucosa and then reaches the dorsal root ganglia termini, from which it is intraxonally transported to the TG, where it replicates or becomes latent. ${ }^{3}$ However, sometimes, for reasons that are not well understood, the virus reaches the brain, where it causes encephalitis. ${ }^{6}$ Using an intranasal inoculum of $10^{4} \mathrm{PFU}$, a previous study from our group demonstrated by immunohistochemistry that only mice with signs of encephalitis expressed viral proteins in brain cells, but all infected mice expressed viral proteins in TG cells 8 d.p.i. ${ }^{23}$ With the higher PFU inoculation used in this study, the virus reached the TG in WT mice around 2 d.p.i. (Table 1; Figure 1A), replicated until 6 d.p.i. (Table 1) and then was controlled by the mice, although the viral VP-16 transcripts remained, in lower amounts, until day 8 postinfection (Figure 1A), which was the last day analyzed. In most of the WT mice, once the virus reached the TG, it stimulated the expression of cytokines and chemokines that control virus replication, preventing most of the infectious virus from reaching the brain. This response seems to be very well regulated because the expression of these molecules in WT mouse TG was more elevated on day 5 postinfection (Figure 1, B-E) -when the virus is replicating in higher amounts and TLR expression is increased (Figure 1F) - and returns to basal levels as soon as the infectious virus particles are controlled. The TLR-dependent immune responses in TG seem to be fundamental for controlling HSV-1 infection and preventing the virus from reaching the brain, where it could cause lethal encephalitis.

Many groups have already shown that TLR2 and TLR9 recognize HSV-1 or HSV-2, which activates an immune response to the virus. ${ }^{20-25}$ Because different viral strains may elicit different responses, ${ }^{31}$ we decided to confirm that our isolate was able to activate those receptors. Using HEK293 cells stably expressing TLRs, we have shown that HSV-1 activates TLR2 and TLR9 but not TLR4 or cells that do not express these receptors (Figure 2). Using similar cell constructs, Kurt-Jones et a ${ }^{20}$ could not detect TLR9 activation on HSV-1 KOS stimulation (but they detected TLR2 activation). Although Kurt-Jones et $\mathrm{al}^{20}$ did not determine whether this was due to a technical limitation, Sato et $\mathrm{a}^{24}$ found similar results when comparing TLR stimulation of HSV-1 KOS and other HSV strains; however, Sato et $\mathrm{al}^{24}$ also demonstrated that, although not recognized by TLR9 in HEK cells, the analyzed virus seemed to use this receptor to stimulate dendritic cell responses. Because different systems seemed to elicit different responses, we investigated whether our HSV-1 strain elicited TLR2 and TLR9 responses in HEK cells and in macrophages. We discovered that both receptors were important for cytokine production in these cells, but the level of importance varied with the type of cytokine. In macrophages (Figure 3), TLR2 and TLR9 contribute to IL12p40 and TNF $\alpha$ production. Although, there seemed to be some cooperation between these receptors for IL12p40 (because the double KO had a lower production when compared with the single KOs), an effect that was not observed for TNF $\alpha$. Thus, the importance of the TLRs varies by cytokine type. 
After we demonstrated that our isolate stimulated TLR2 and TLR9 in vitro and ex vivo, we analyzed the roles of these receptors in vivo. C57BL/6 WT, $\mathrm{TLR2}^{-1-}$, $\mathrm{TLR9}^{-1-}$, and TLR2 $/ 9^{-1-}$ mice were infected with HSV-1, and the mortality rates indicated that TLR2 plays a minor role in mouse survival because TLR2 ${ }^{-1-}$ mice had a low mortality rate that was very similar to that of WT mice (Figure 4). TLR9 seemed to play a major role in infection control because null animals showed a higher mortality rate compared with WT mice (Figure 4). In a previous study, ${ }^{23}$ it was shown that MyD88 is fundamental for immune defense against HSV-1, with $100 \%$ mortality observed in

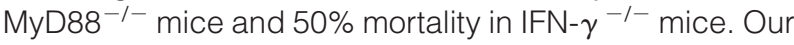
data strongly suggested, for the first time, that TLR2 and TLR9 cooperate in vivo to induce this MyD88-dependent response in HSV-1 infected mice; we showed that infection of TLR2/ $/ 9^{-1-}$ mice results in $100 \%$ mortality (Figure 4), as previously shown for MyD88 ${ }^{-/-}$mice. All animals that died with signs of encephalitis (prostration, ruffled fur, hunched posture, and posterior paw paralysis) had infectious virus particles in their brains, which were not observed for animals without signs of encephalitis (Table 2). Therefore, the presence of infectious HSV-1 in mouse brains correlated with the signs of encephalitis and death, as previously shown. ${ }^{23,39}$ The virus titers were

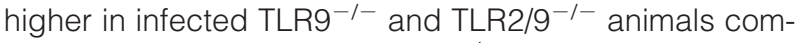
pared with infected WT or TLR2 ${ }^{-1-}$ animals (Table 2).

The analysis of cytokine and chemokine expression indicated that high expression of CXCL10/IP-10 and CCL2/MCP-1 was related to deaths because infected TLR2/9 ${ }^{-1-}$ mice had an increased level of these chemokines in the TG and brain (Figures 6 and 7). Kurt-Jones et $\mathrm{al}^{20}$ have already shown that mice that succumbed to HSV-1 infection have high levels of the CCL2/MCP-1 transcript in the brain. Although it may be important to control the virus, CXCL10/IP-10 could also have some deleterious role in HSV-1 infection because mice treated with an anti-CXCL10 antibody showed prolonged survival, even though viral yields were significantly greater in the infected tissue. ${ }^{40}$ Importantly, we show a correlation between low levels of IFN- $\gamma$ and IL-1 $\beta$ transcripts in TG and poor survival; all infected knockout mice showed reduced expression of IFN- $\gamma$ in TG (Figure 6). In WT mice, the level of IFN- $\gamma$ in TG would already be sufficient to control the virus, whereas the TLR2 ${ }^{-1-}$ mice still produced IFN- $\gamma$ in the brain because production in the TG was lower than in WT mice (Figures 6 and 7).

Unlike $\mathrm{TLR}^{-1-}$ mice, TLR2 $/ 9^{-1-}$ mice had high amounts of virus in the brain (Table 2), and the absence of IFN- $\gamma$ in brains of the latter (Figure 7) seems to be important for their immune response. IFN- $\gamma$ possesses an important antiviral potential and is capable of controlling viral replication during the early phases of infection. ${ }^{41}$ Additionally, $\mathrm{He}$ et $\mathrm{al}^{42}$ also found that IFN $\gamma$-deficient mice had a higher mortality rate and delayed virus clearance after an ocular inoculation of the HSV-1 Amakata strain. However, as we have reported previously, ${ }^{23} 50 \%$ of $\mathrm{IFN}-\gamma^{-I-}$ mice died when infected with HSV-1, whereas all infected MyD88 ${ }^{-1-}$ mice died. Therefore, although expression of IFN- $\gamma$, either in the TG or brain, is necessary to control the virus, there must be another
MyD88-dependent process that is important for total immune defense against HSV-1. Interestingly, IL- $1 \beta$ signaling is MyD88 dependent. ${ }^{43}$ It has been shown that IL-1 $\beta$ plays a critical role in Herpes Simplex virus encephalitis; in an intranasal murine model of infection with HSV-1 strain H25, IL-1 knockout mice had lethal encephalitis, higher brain viral loads, and inadequate immune responses in the brain. ${ }^{44} \mathrm{IL}-1 \beta$ also has a role in promoting the repair of the central nervous system. ${ }^{45}$ We observed that IL-1 $\beta$ expression levels were significantly reduced in infected TLR2/ $/ 9^{-1-}$ mice TG and brains (Figures 6 and 7), and it was not reduced in the TG of infected $\mathrm{TLR}^{-1-}$ or TLR2 $2^{-1-}$ mice (Figure 6). This cytokine was also not reduced in the brain of TLR2 ${ }^{-1-}$ mice (Figure 7 ), and it was reduced in $\mathrm{TLR9}^{-1-}$ mice, although it was not statistically lower compared with expression in WT mice. This reduction in IL-1 $\beta$ could explain why TLR2 $2^{-/-}$and $\mathrm{TLR9}^{-1-}$ mice have a insignificant or only $60 \%$ mortality, respectively, compared with $100 \%$ mortality in TLR2/ $9^{-1-}$ mice, even though both $\mathrm{TLR}^{-1-}$ and $\mathrm{TLR9}^{-1-}$ mice, as well as TLR2/ $/ 9^{-1-}$ mice, produced lower levels of IFN- $\gamma$ in the TG compared with WT mice. Additionally, TLR2 ${ }^{-1-}$ mice showed a higher level of IFN- $\gamma$ expression in the brain (Figure 7) and a higher expression level of IL-1 $\beta$ in the TG and brain (Figures 6 and 7) compared with TLR2/ $9^{-1-}$ mice; this increased cytokine expression could be responsible for the effective immune response against HSV-1 in this knockout mouse.

Our results showed that IFN $\beta$ and MIP1 $\alpha$ were upregulated in the TG of all groups of infected mice compared with uninfected mice (data not shown). Although important in HSV control, ${ }^{46-48}$ expression of these molecules probably does not depend on TLR2 or TLR9 in the TG.

Furthermore, TLR2 $/ 9^{-1-}$ infected mice have major histopathological alterations in the brain compared with those observed in WT brains or in the brains of the other knockout mice evaluated (Figure 5; Table 3). The brain parenchyma of TLR2/ $/ 9^{-/-}$mice had focal lesions, and the infiltration of meninges was visibly more intense than the degenerative changes in the brain parenchyma. Brain meninges were compromised in infected TLR2/ $9^{-1-}$ mice, as shown by the massive presence of inflammatory cells inside and outside the meningeal vessels. Similar brain alterations were found in susceptible mice in another study. ${ }^{20}$ Marques et al ${ }^{49}$ suggested that neurological damage might be related to CXCL10/IP-10 and CCL2/MCP-1 production and that these chemokines are probably microglia derived, a hypothesis that demands further in vivo and in vitro investigation. Our data indicated that TLR2 $/ 9^{-1-}$ mice had significantly higher histopathology scores (brain and meninges) than WT and TLR2 ${ }^{-1-}$ mice, but the differences were less apparent when compared with $\mathrm{TLRO}^{-1-}$ mice.

Together, the results indicate that although TLR9 seems to have a more critical role in vivo than TLR2, both receptors are not only important receptors in HSV-1 recognition and control but also may cooperate in the activation of the immune response because the double knockout mice had higher mortality rates and more prominent immune alterations and brain pathology on day 5 postinfection. Immunological and pathological alterations 
were not as evident in $\mathrm{TLR9}^{-1-}$ mice, probably due to

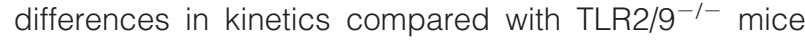
because the latter began to die earlier than the former. Additionally, IFN $\beta$ and CCL3/MIP $1 \alpha$ transcripts had similar expression levels in the TG for all groups of animals, suggesting that other receptors could be involved and that other pattern recognition receptors may also contribute to HSV-1 control. Retinoic acid inducible genelike receptors and DNA-dependent activator of IFN regulatory factors are some of the pattern recognition receptors that have also been shown to recognize HSV. ${ }^{50,51}$

Finally, we have shown that infection control depends on an immune response in the TG and brain in the herpes intranasal model. HSV-1 control seems to be mainly local because the only cytokine profile altered in knockout susceptible mice sera was that of CCL2/MCP1 (Figure 7F). The response in the TG seems to limit virus replication to prevent too much virus (if any) from reaching the brain-an essential process to prevent encephalitis. The response in the brain may not only be an attempt to contain the virus but also may be designed to prevent brain damage. These responses must be well regulated because not only the virus but also the immune response itself may cause tissue damage and encephalitis. ${ }^{52}$ This indicates that, in addition to activating cytokine and chemokine production, TLRs may have a role in the regulation of the immune response. This idea is corroborated by recent findings that indicate that TLRs may suppress the immune response of T cells and NK cells, ${ }^{53}$ control B cells responses, ${ }^{54}$ transiently silence pro-inflammatory genes, ${ }^{55}$ modulate chemokine receptors, and redirect leukocyte migration. ${ }^{56}$ Because the brain histopathology 5 d.p.i. showed mononuclear infiltration only in the meninges of TLR2/ $/ 9^{-1-}$ mice, we must further investigate TLR participation in HSV-1 control by identifying all of the cells that are responsible for cytokine/chemokine production in the TG and brains of resistant and susceptible mice. However, on day 5 postinfection the TG of WT infected mice show increased cellularity of the ganglia root and in areas close to neurons, where many small mononuclear cells were detected by Giemsa staining and macrophages were detected by flow cytometry. These mononuclear cells could be the TLR-producing cells. Additionally, cells of the TG from infected mice showed positive immunostaining for CD8 $T$ cells and produced higher levels of IFN- $\gamma$, which we showed by flow cytometry. Our next goal is to study in detail each cell of the TG that participates in the immune response and its respective cytokine. The data from this work showed that the immune response in the TG is crucial to prevent against encephalitis, contributing to the understanding of innate immune responses to HSV-1 and may, in the future, provide some clues to aid in the fight against viral brain pathogens.

\section{Acknowledgments}

We thank Dr. Douglas T. Golenbock (University of Massachusetts Medical School) for providing us with the HEK cell lines; Dr. Shizuo Akira (Osaka, Japan) for providing the TLR2 ${ }^{-I-}$ and $\mathrm{TLR}^{-/-}$mice; and Dr. Alan Sher $(\mathrm{NIH}$,

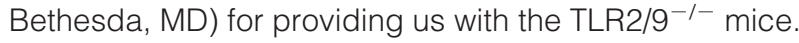

\section{References}

1. Cowan FM, French RS Mayaud P, Gopal R, Robinson NJ, Artimos de Oliveira S, Faillace T, Uusküla A, Nygard-Kibur M, Ramalingam S, Sridharan G, El Aouad R, Alami K, Rbai M, Sunil-Chandra NP, Brown DW: Seroepidemiological study of herpes simplex virus types 1 and 2 in Brazil, Estonia, India, Morocco and Sri Lanka. Sex Transm Infect 2003, 79:286-290

2. Fatahzadeh M, Schwarz RA: Human herpes simplex virus infections: Epidemiology, pathogenesis, symptomatology, diagnosis, and management. J Am Acad Dermatol 2007, 57:737-763

3. Roizman B, Knipe DM, Whitley RJ: Herpes Simplex Viruses. Fields virology ed 5. Edited by DM Knipe, RM Howley. Philadelphia, Lippincott Williams \& Wilkins, 2007, pp 2501-2576

4. Garner JA: Herpes simplex virion entry into and intracellular transport within mammalian cells. Advanced Drug Delivery Reviews 2003, 55:1497-1513

5. Theil D, Derfuss T, Paripovic I, Herberger S, Meinl E, Schueler O Strupp M, Arbusow V, Brandt T: Latent Herpes virus infection in human trigeminal ganglia causes chronic immune response. Am J Pathol 2003, 163:2179-2184

6. Whitley RJ: Herpes simplex encephalitis: adolescents and adults Antiviral Res 2006, 71:141-148

7. Ishii KJ, Koyama S, Nakagawa A, Coban C, Akira S: Host innate immune receptors and beyond: making sense of microbial infections. Cell Host Microbe 2008, 3:352-363

8. Rasmussen SB, Reinert LS, Paludan SR: Innate recognition of intracellular pathogens: detection and activation of the first line of defense. APMIS 2009, 117:323-337

9. Takeuchi O, Hoshino K, Kawai T, Sanjo H, Takada H, Ogawa T, Takeda K, Akira S: Differential roles of TLR2 and TLR4 in recognition of Gram negative and Gram positive bacterial cell wall components. Immunity 1999, 11:443-451

10. Campos MA, Almeida IC, Takeuchi O, Akira S, Paganini E, Procópio DO, Travassos LR, Smith JA, Golenbock DT, Gazzinelli RT: Activation of Toll-like receptor-2 by glycosylphosphatidylinositol anchors from a protozoan parasite. J Immunol 2001, 167:416-423

11. Campos MA, Rosinha GMS, Almeida IC, Salgueiro XS, Jarvis BW, Splitter GA, Bruna-Romero O, Gazzinelli RT, Oliveira SC: The role of Toll-like receptor 4 in induction of cell-mediated immunity and resistance to Brucella abortus infection in mice. Infect Immun 2004, 72:176-186

12. Latz E, Visintin A, Lien E, Fitzgerald KA, Monks BG, Kurt-Jones EA, Golenbock DT, Espevik T: Lipopolysaccharide rapidly traffics to and from the Golgi apparatus with the toll-like receptor 4-MD-2-CD14 complex in a process that is distinct from the initiation of signal transduction. J Biol Chem 2002, 277:47834-47843

13. Lien E, Means TK, Heine H, Yoshimura A, Kusumoto S, Fukase K, Fenton MJ, Oikawa M, Qureshi N, Monks B, Finberg RW, Ingalls RR, Golenbock DT: Toll-like receptor 4 imparts ligand-specific recognition of bacterial lipopolysaccharide. J Clin Invest 2000, 105:497-504

14. Poltorak A, He X, Smirnova I, Liu MY, Van Huffel C, McNally O, Birdwell D, Alejos E, Silva M, Galanos C, Freudenberg M, RicciardiCastagnoli $\mathrm{P}$, Layton B, Beutler B: Defective LPS signaling in $\mathrm{C} 3 \mathrm{H} /$ HeJ and C57BL/10ScCr mice: mutations in TLR4 gene. Science 1998, 282:2085-2088

15. Alexopoulou L, Holt AC, Medzhitov R, Flavell RA: Recognition of double-stranded RNA and activation of NFkB by Toll-like receptor 3 . Nature 2001, 413:432-438

16. Hayashi F, Smith KD, Ozinsky A, Hawn TR, Yi EC, Goodlett DR, Eng JK, Akira S, Underhill DM, Aderem A: The innate immune response to bacterial flagelin is mediated by Toll-like receptor 5. Nature 2001 , 410:1099-1103

17. Hemmi H, Takeuchi O, Kawai T, Kaisho T, Sato S, Sanjo H, Matsumoto M, Hoshino K, Wagner H, Takeda K, Akira S: A Toll-like receptor recognizes bacterial DNA. Nature 2000, 408:740-745

18. Takeda K, Kaisho T, Akira S: Toll-like receptors. Annu Rev Immunol 2003, 21:335-376

19. Yamamoto M, Takeda K, Akira S: TIR domain-containing adaptors 
define the specificity of TLR signaling. Mol Immunol 2004, 40:861-868

20. Kurt-Jones EA, Chan M, Zhou S, Wang J, Reed G, Bronson R, Arnold MM, Knipe DM, Finberg R W: Herpes simplex virus 1 interaction with toll-like receptor 2 contributes to lethal encephalitis. Proc Natl Acad Sci USA 2004, 101:1315-1320

21. Hochrein H, Schlatter B, O'Keeffe M, Wagner C, Schmitz F, Schiemann M, Bauer S, Suter M, Wagner H: Herpes simplex virus type-1 induces IFN-alpha production via Toll-like receptor 9-dependent and -independent pathways. Proc Natl Acad Sci USA 2004, 101 $11416-11421$

22. Krug A, Luker GD, Barchet W, Leib DA, Akira S, Colonna M: Herpes simplex virus type 1 (HSV-1) activates murine natural interferonproducing cells (IPC) through Toll-like receptor 9. Blood 2004, 103:1433-1437

23. Mansur DS, Kroon EG, Nogueira ML, Arantes RME, Rodrigues SCO, Akira S, Gazzinelli RT, Campos MA: Lethal encephalitis in myeloid differentiation factor 88: deficient mice infected with herpes simplex virus 1. Am J Pathol 2005, 166:1419-1426

24. Sato A, Linehan MM, Iwasaki A: Dual recognition of herpes simplex viruses by TLR2 and TLR9 in dendritic cells. Proc Natl Acad Sci USA 2006, 103:17343-17348

25. Sorensen LN, Reinert LS, Malmgaard L, Bartholdy C, Thomsen AR, Paludan SR: TLR2 and TLR9 synergistically control herpes simplex virus infection in the brain. J Immunol 2008, 181:8604-8612

26. Casrouge A, Zhang S, Eidenschenk C, Jouanguy E, Puel A, Yang K, Alcais A, Picard C, Mahfoufi N, Nicolas N, Lorenzo L, Plancoulaine S, Sénéchal B, Geissmann F, Tabeta K, Hoebe K, Du X, Miller RL, Héron B, Mignot C, de Villemeur TB, Lebon P, Dulac O, Rozenberg F, Beutler B, Tardieu M, Abel L, Casanova JL: Herpes simplex virus encephalitis in human UNC-93B deficiency. Science 2006, 314: 308-312

27. Zhang S, Jouanguy E, Ugolini S, Smahi A, Elain G, Romero P, Segal D, Sancho-Shimizu V, Lorenzo L, Puel A, Picard C, Chapgier A, Plancoulaine S, Titeux M, Cognet C, von Bernuth $\mathrm{H}, \mathrm{Ku} C \mathrm{C}$, Casrouge A, Zhang XX, Barreiro L, Leonard J, Hamilton C, Lebon P, Héron B, Vallée L, Quintana-Murci L, Hovnanian A, Rozenberg F, Vivier E, Geissmann F, Tardieu M, Abel L, Casanova JL: TLR3 deficiency in patients with herpes simplex encephalitis. Science 2007, 317: 1522-1527

28. Nogueira ML, Siqueira RC, Freitas N, Amorim JB, Bonjardim CA, Ferreira PC, Orefice F, Kroon EG: Detection of herpesvirus DNA by the polymerase chain reaction (PCR) in vitreous samples from patients with necrotising retinitis. J Clin Pathol 2001, 54:103-106

29. Campos MA, Kroon EG: Critical period of irreversible block of Vaccinia virus replication. Rev Bras Microbiol 1993, 24:104-110

30. Boivin G, Coulombe Z, Rivest S: Intranasal herpes simplex virus type 2 inoculation causes a profound thymidine kinase dependent cerebral inflammatory response in the mouse hindbrain. Eur $\mathrm{J}$ Neurosci 2002, 16:29-43

31. Schmidt NJ: Cell culture techniques for diagnostic virology. Diagnostic Procedures for Viral, Rickettsial, and Chlamydial Infections. Edited by EH Lennette, NJ Schmidt. Washington DC, American Public Health Association Inc, 1979, p 100

32. Giulietti A, Overbergh L, Valckx D, Decallonne B, Bouillon R, Mathieu C: An overview of real-time quantitative PCR: applications to quantify cytokine gene expression. Methods 2001, 25:386-401

33. Broberg EK, Nygardas M, Salmi AA, Hukkanen V: Low copy number detection of herpes simplex virus type 1 mRNA and mouse Th1 type cytokine mRNAs by light cycler quantitative real time PCR. J Virol Methods 2003, 112:53-65

34. Kuhlicke J, Frick JS, Morote-Garcia JC, Rosenberger P, Eltzschig HK: Hypoxia inducible factor (HIF)-1 coordinates induction of toll-like receptors TLR2 and TLR6 during hypoxia. PLoS One 2007, 2:e1364

35. Préhaud $C$, Mégret $F$, Lafage M, Lafon M: Virus infection switches TLR3 positive human neurons to become strong producers of beta interferon. J Virol 2005, 79:12893-12904

36. Sarangi PP, Kim B, Kurt-Jones E, Rouse BT: Innate recognition net- work driving the HSV induced corneal immunopathology: role of Toll pathway in the early inflammatory events in stromal keratitis. J Virol 2007, 81:11128-11138

37. Sancho-Shimizu V, Shen-Ying Z, Laurent A, Tardieu M, Rozemberg F, Jouanguy E, Casanova J: Genetic susceptibility to herpes simplex virus 1 encephalitis in mice and humans. Curr Opin Allergy Clin Immunol 2007, 7:495-505

38. Kern ER: Use of viral infections in animal models to assess changes in the immune system. EHP 1982, 43:71-79

39. Lopez C: Genetics of natural resistance to herpesvirus infections in mice. Nature 1975, 258:152-153

40. Carr DJJ, Chodosh J, Ash J, Lane TE: Effect of anti-CXCL10 monoclonal antibody on Herpes Simplex Virus Type 1 keratitis and retinal infection. J Virol 2003, 77:10037-10046

41. Ellerman-Eriksen S: Macrophages and cytokines in the early defense against herpes simplex virus. Virol J 2002, 2:59-89

42. He J, Ichimura H, lida T, Minami M, Kobayashi K, Kita M, Sotozono C, Tagawa $\mathrm{Y}$, Iwakura $\mathrm{Y}$, Imanishi J: Kinetics of cytokine production in the cornea and trigeminal ganglion of C57BL/6 mice after corneal HSV-1 infection. J Interferon Cytokine Res 1999, 19:609-615

43. Sun D, Ding A: MyD88-mediated stabilization of interferon-gammainduced cytokine and chemokine mRNA. Nature Immunol 2006, 7:375-381

44. Sergerie $Y$, Rivest S, Boivin G: Tumor necrosis factor-alpha and interleukin-1beta play a critical role in the resistance against lethal herpes simplex virus encephalitis. J Infect Dis 2007, 196:853-860

45. Mason JL, Suzuki K, Chaplin DD, Matsushima GK: Interleukin 1-beta promotes repair of the CNS. J Neurosci 2001, 21:7046-7052

46. Carr DJJ, Campbell IL: Herpes simplex virus type 1 induction of chemokine production is unrelated to viral load in the cornea but not in the nervous system. Viral Immunol 2006, 19:741-746

47. Sainz Jr., B, Halford WP: Alpha/Beta Interferon and gamma interferon synergize to inhibit the replication of herpes simplex virus type 1. J Virol 2002, 76:11541-11550

48. Vollstedt S, Arnold S, Schwerdel C, Franchini M, Alber G, Di Santo JP, Ackermann M, Suter M: Interplay between alpha/beta and gamma interferons with $\mathrm{B}, \mathrm{T}$, and natural killer cells in the defense against herpes simplex virus type 1. J Virol 2004, 78:3846-3850

49. Marques CP, Hu S, Sheng W, Lokensgard JR: Microglial cells initiate vigourous yet non-protective immune responses during HSV-1 brain infection. Virus Res 2006, 121:1-10

50. Rasmussen SB, Jensen SB, Nielsen C, Quartin E, Kato H, Chen ZJ, Silverman RH, Akira S, Paludan SR: Herpes simplex virus infection is sensed by both Toll-like receptors and retinoic acid-inducible genelike receptors, which synergize to induce type I interferon production. J Gen Virol 2009, 90:74-78

51. Takaoka A, Wang Z, Choi MK, Yanai H, Negishi H, Ban T, Lu Y, Miyagishi M, Kodama T, Honda K, Ohba Y, Taniguchi T: DAI (DLM1/ZBP1) is a cytosolic DNA sensor and an activator of innate immune response. Nature 2007, 448:501-505

52. Lundberg $\mathrm{P}$, Ramakrishna $\mathrm{C}$, Brown J, Tyska JM, Hamamura M, Hinton DR, Kovats S, Nalcioglu O, Weinberg K, Openshaw H, Cantin EM: The immune response to herpes simples virus type 1 infection in susceptible mice is a major cause of central nervous system pathology resulting in fatal encephalitis. J Virol 2008, 82:7078-7088

53. Vaknin V, Blinder L, Wang L, Gazit R, Shapira E, Genina O, Pines M, Pikarsky E, Baniyash M: A common pathway mediated through Tolllike receptors leads to $\mathrm{T}$ - and natural killer-cell immunosuppression. Blood 2008, 111:1437-1447

54. Pasare C, Medzhitov R: Control of B-cell responses by Toll-like receptors. Nature 2005, 438:364-368

55. Foster SL, Hargreaves DV, Medzhitov R: Gene-specific control of inflammation by TLR-induced chromatin modifications. Nature 2007, 447:972-978

56. McKimmie CS, Moore M, Fraser AR, Jamieson T, Xu D, Burt C, Pitman NI, Nibbs RJ, Mclnnes IB, Liew FY, Graham GJ: A TLR2 ligand suppresses inflammation by modulation of chemokine receptors and redirection of leukocyte migration. Blood 2009, 113:4224-4231 